\title{
Cochlear implants: our experience and literature review
}

\author{
Mariane Barreto Brandão Martins', Francis Vinicius Fontes de Lima', Ronaldo Carvalho Santos Júnior ${ }^{2}$, Arlete Cristina Granizo \\ Santos ${ }^{3}$, Valéria Maria Prado Barreto ${ }^{4}$, Eduardo Passos Fiel de Jesus ${ }^{3}$.
}

1) Doctor. Specializing in Otolaryngology.

2) Doctor of Medicine (Otolaryngology), University of Sao Paulo. Head of the Department of Otorhinolaryngology, University Hospital, Faculty of Medicine, Federal University of Sergipe.

3) Otorhinolaryngologist. Teacher of the Residents of Otorhinolaryngology of the University Hospital of the Faculty of Medicine of the Federal University of Sergipe. 4) Master of Health Sciences, Federal University of Sergipe. Teacher of the Residents of Otorhinolaryngology of the University Hospital of the Faculty of Medicine of the Federal University of Sergipe.

Institution: Universidade Federal de Sergipe. Aracaju / SE - Brazil.

Mailing address: Mariane Barreto Brandão Martins - Rua Deputado Antônio Torres, 699 - Condomínio Vila do Sol - Apto. 102A - Bairro: Pereira Lobo. Aracaju / SE - Brazil - Zip code: $49052-050$ - Telephone: (+55 79) 9924-4118 / 3222-8388 - E-mail: mari.ane_martins@yahoo.com.br

Article received in April 19, 2012. Article approved in July 31, 2012.

\section{SUMMARY}

Introduction: Cochlear Implants are important for individuals with severe to profound bilateral sensorineural hearing loss. Objective: Evaluate the experience of cochlear implant center of Otorhinolaryngology through the analysis of records of 9 patients who underwent cochlear implant surgery.

Methods: This is a retrospective study performed with the patients records. Number 0191.0.107.000-11 ethics committee approval. We evaluated gender, etiology, age at surgery, duration of deafness, classification of deafness, unilateral or bilateral surgery, intraoperative and postoperative neural response and impedance of the electrodes in intraoperative and preoperative tests and found those that counter-indicated surgery.

Results: There were 6 pediatric and 3 adult patients. Four male and 5 female. Etiologies: maternal rubella, cytomegalovirus, ototoxicity, meningitis, and sudden deafness. The age at surgery and duration of deafness ranged from $2-46$ years and $2-$ 18 years, respectively. Seven patients were pre-lingual. All had profound bilateral PA. There were 7 bilateral implants. Intraoperative complications: hemorrhage. Complications after surgery: vertigo and internal device failure. In 7 patients the electrodes were implanted through. Telemetry showed satisfactory neural response and impedance. CT and MRI was performed in all patients. We found enlargement of the vestibular aqueduct in a patient and incudomalleolar malformation.

Conclusion: The cochlear implant as a form of auditory rehabilitation is well established and spreading to different centers specialized in otoaudiology. Thus, the need for structured services and trained professionals in this type of procedure is clear. Keywords: cochlear implants; hearing loss; hearing loss, sensorineural.

\section{INTRODUCTION}

The hearing deficiency is a pathology that interferes in several aspects of the emotional, psychological, social and intellectual life. So, to solve this problem is of basic importance for the good development of the communication and consequently of whose social inclusion it has.

Cochlear Implants (CI) are electronic devices that allow hearing rehabilitation of individuals with severe profound bilateral sensorineural hearing lossl1, that did not benefit with the use of individual appliances of resonant enlargement individual2. CIs stimulate electrically the fibers of the hearing nerve, substituting in partial for the function of the cochlea3. Worldwide, more than 120.000 patients were introduced with different types of implants, obtaining better results to each day 4 . These good results are attributed much to the technology of the appliance, that is improving regularly, as well as with the growing experience of the surgeons.

The present study aims to assess the experience of the Service of Otorhinolaryngology of the University Hospital of the Federal University of Sergipe with patients who have undergone CI surgery.

\section{MetHOD}

The study is a retrospective cohort study and it was carried out by means of information obtained through diaries of 9 patients who underwent CI surgery in the Service of Otorhinolaryngology of the University Hospital of the Federal University of Sergipe.

The patients were analyzed by gender etiology, age at the time of surgery, duration of deafness, classification of the deafness, type of implant, joined surgery or bilateraly, 


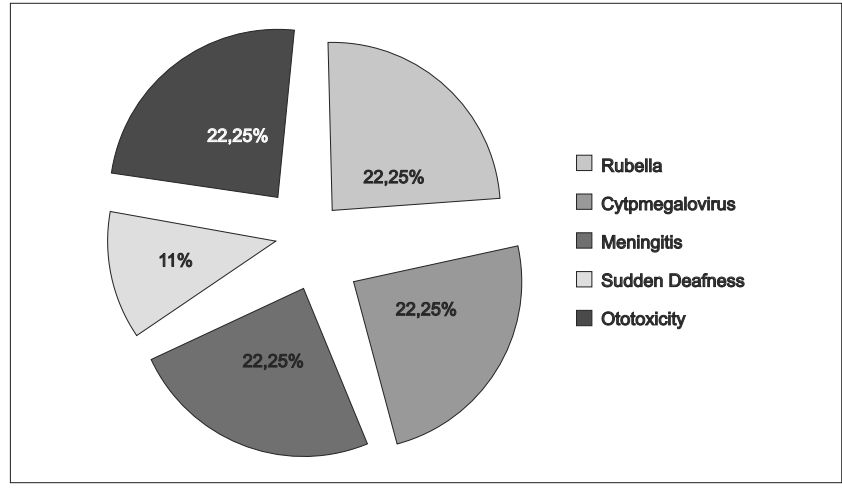

Figure 1. Etiology of hearing loss.

intra-operative complications, post-operative complications, impedance and neural answer from the electrodes to the intra-operative telemetry, evaluation audiological powdersimplants, preoperative radiological examinations and radiologic findings that were counter-indicated in the surgery.

\section{RESULTS}

In our study, 9 patients who underwent CI surgery of implant cochlear, 6 were children and 3 were adults, 4 males and 5 females. The causes are outlined in Figure 1. The time of surgery and the duration of deafness varied with age from 2 to 46 years and from 2 to 18 years, respectively. Seven patients were classified like lingualdaily pay and 2 like lingual-powders. All presented with profound bilateral hearing loss, with the exception of a patient, who presented with profound severe hearing loss on the right. The CI used was the Nucleus Freedom in 8 of 9 patients, being that 5 had the Nucleus 5 speech processor of and 3 others had the Nucleus Freedon speech processor. Only one patient received the implant the implant cochlear of the type Sonata with speech processor Opus 1. In 2 of 9 patients, a straight electrodes bundle was used, since these patients had meningitis as the etiology of the deafness and so had the possibility of an ossified cochlea. A third patient also had a straight electrodes bundle when it was needed to carry out the exchange of the appliance for fault of the internal device. This decision was made considering the possibility of fibrosis and larger difficulty in the passage of the electrodes. In 7 of 9 patients, the implant was carried out bilaterally. As to intra-operative complications, we had hemorrhage in only 1 patient. The complications in the post-operative period are presented in Chart 2. Only 1 patient is presented, who after 2 months of the activation of the implant, faulty in an internal component of the appliance, presented to the realization of another surgical proceeding being necessary, with the
Chart I. Characteristics of 9 evaluated patients.

\begin{tabular}{|c|c|}
\hline \multicolumn{2}{|c|}{ Characteristics of 9 Evaluated Patients } \\
\hline & $N(\%)$ \\
\hline \multicolumn{2}{|l|}{ Age inthe ICsurgery } \\
\hline 2 years & | ( $|1| \%)$. \\
\hline 4 years & I ( $11.1 \%)$ \\
\hline 5 years & $2(22.2 \%)$ \\
\hline 6 years & | ( $|1| \%)$. \\
\hline 9 years & $1(11.1 \%)$ \\
\hline 17 years & $\mid(\mid 1.1 \%)$ \\
\hline 20 years & $1(11.1 \%)$ \\
\hline 46 years & I ( $\mid 1.1 \%)$ \\
\hline \multicolumn{2}{|l|}{ Sex } \\
\hline Female & $5(55.5 \%)$ \\
\hline Male & $4(44.4 \%)$ \\
\hline \multicolumn{2}{|l|}{ Time of the hearing loss } \\
\hline | year(lingual-powders) & | ( $|1| \%)$. \\
\hline 2 years(lingual-daily pay) & $\mid(|| . \mid \%)$ \\
\hline 4 years (lingual-daily pay) & $\mid(|| . \mid \%)$ \\
\hline 5 years (lingual-daily pay) & $2(22.2 \%)$ \\
\hline 6 years (lingual-daily pay) & | ( $\mid 1.1 \%)$ \\
\hline 9 years(lingual-daily pay) & | ( $\mid 1.1 \%)$ \\
\hline 13 years(lingual-powders) & $\mid(|| . \mid \%)$ \\
\hline | 8 years (lingual-daily pay) & | ( $\mid 1.1 \%)$ \\
\hline \multicolumn{2}{|l|}{ Time of use of the implant } \\
\hline I month & $4(44.4 \%)$ \\
\hline 5 months & | ( $|1| \%)$. \\
\hline 7 months & | ( $|1| \%)$. \\
\hline 10 months & I ( $|1| \%)$. \\
\hline 20 months & $\mid(|| . \mid \%)$ \\
\hline 28 months & | ( $|.| . \mid \%)$ \\
\hline \multicolumn{2}{|l|}{ Introducedear } \\
\hline EarR & $\mid(|| . \mid \%)$ \\
\hline EarL & $\mid(|| . \mid \%)$ \\
\hline Both & $7(77.8 \%)$ \\
\hline
\end{tabular}

Chart 2. Complications surgical-powders of the patients wrapped in the work.

\begin{tabular}{lccc}
\hline $\begin{array}{l}\text { Complications } \\
\text { surgical-powders }\end{array}$ & $\begin{array}{c}\text { Classification of } \\
\text { the complication }\end{array}$ & $\begin{array}{c}\text { No. } \\
\text { of cases }\end{array}$ & $\begin{array}{c}\% \text { of } \\
\text { the total }\end{array}$ \\
\hline Dizziness & Less & $\mid$ & $11.1 \%$ \\
Faultofthe device & Bigger & $\mid$ & $11.1 \%$ \\
\hline Total & - & 2 & $22.2 \%$ \\
\hline
\end{tabular}

Chart 3. Found in examinations of image (TC and RNM).

\begin{tabular}{lcc}
\hline When the CT and RNM found to & $\begin{array}{c}\text { No. of } \\
\text { the cases }\end{array}$ & $\begin{array}{c}\% \text { of } \\
\text { the total }\end{array}$ \\
\hline Badlyformation & $\mid$ & $11.1 \%$ \\
Extended vestibularaqueduct & 1 & $11.1 \%$ \\
\hline Total & 2 & $22.2 \%$ \\
\hline
\end{tabular}


Chart 4. Hearing discrimination of the first 5 operated patients.

\begin{tabular}{|c|c|c|c|c|c|}
\hline Hearing discrimination & $\begin{array}{l}\text { IPC: } 2 \text { years } \\
\text { TPS: } 2 \text { years } \\
\text { TI: } 10 \text { months }\end{array}$ & $\begin{array}{l}\text { IPC: } 5 \text { years } \\
\text { TPS: } 5 \text { years } \\
\text { TI: } 7 \text { months }\end{array}$ & $\begin{array}{l}\text { IPC: } 9 \text { years } \\
\text { TPS: } 9 \text { years } \\
\text { TI: } 5 \text { months }\end{array}$ & $\begin{array}{l}\text { IPC: } 4 \text { years } \\
\text { TPS: } 4 \text { years } \\
\text { TI:20 months }\end{array}$ & $\begin{array}{l}\text { IPC: } 20 \text { years } \\
\text { TPS: } 18 \text { years } \\
\text { TI:28 months }\end{array}$ \\
\hline Monosyllabic & - & $x$ & - & X & X \\
\hline Dissyllabic & - & X & - & $x$ & X \\
\hline Syllableswithoutsense & - & - & - & - & - \\
\hline Sentences & - & - & - & - & - \\
\hline Phonemes & - & - & - & - & X \\
\hline Word & - & X & - & - & X \\
\hline
\end{tabular}

Chart 5. Categories of language in the first 5 patients.

\begin{tabular}{|c|c|c|c|c|c|}
\hline Categorias Linguagem & $\begin{array}{l}\text { IPC: } 2 \text { years } \\
\text { TPS: } 2 \text { years } \\
\text { TI: I } 0 \text { months }\end{array}$ & $\begin{array}{l}\text { IPC: } 5 \text { years } \\
\text { TPS: } 5 \text { years } \\
\text { TI: } 7 \text { months }\end{array}$ & $\begin{array}{l}\text { IPC: } 9 \text { years } \\
\text { TPS: } 9 \text { years } \\
\text { TI: } 5 \text { months }\end{array}$ & $\begin{array}{l}\text { IPC: } 4 \text { years } \\
\text { TPS: } 4 \text { years } \\
\text { TI:20 months }\end{array}$ & $\begin{array}{l}\text { IPC: } 20 \text { years } \\
\text { TPS: } 18 \text { years } \\
\text { TI: } 28 \text { months }\end{array}$ \\
\hline Notspeak & $x$ & $\mathrm{x}$ & $x$ & $\mathrm{x}$ & - \\
\hline Emission of isolated words & - & X & - & - & X \\
\hline Emission of simple sentences & - & & - & & - \\
\hline Emission of complex sentences & - & - & - & - & - \\
\hline Fluent & - & - & - & - & - \\
\hline
\end{tabular}

Chart 6. Hearing skills of the first 5 operated patients.

\begin{tabular}{|c|c|c|c|c|c|}
\hline Hearingskills & $\begin{array}{l}\text { IPC: } 2 \text { years } \\
\text { TPS: } 2 \text { years } \\
\text { TI: } 10 \text { months }\end{array}$ & $\begin{array}{l}\text { IPC: } 5 \text { years } \\
\text { TPS: } 5 \text { years } \\
\text { TI: } 7 \text { months }\end{array}$ & $\begin{array}{l}\text { IPC: } 9 \text { years } \\
\text { TPS: } 9 \text { years } \\
\text { TI: } 5 \text { months }\end{array}$ & $\begin{array}{l}\text { IPC: } 4 \text { years } \\
\text { TPS: } 4 \text { years } \\
\text { TI:20 months }\end{array}$ & $\begin{array}{l}\text { IPC: } 20 \text { years } \\
\text { TPS: } 18 \text { years } \\
\text { TI: } 28 \text { months }\end{array}$ \\
\hline Attention & $x$ & $x$ & $x$ & $x$ & $x$ \\
\hline Detection & $x$ & $x$ & $x$ & $x$ & $x$ \\
\hline Location & $x$ & $x$ & $x$ & - & $x$ \\
\hline Discrimination & - & $x$ & - & - & $x$ \\
\hline Recognition & - & - & - & - & - \\
\hline
\end{tabular}

Chart 7. Sounds of the Ling of the first 5 operated patients.

\begin{tabular}{lccccc}
\hline Sounds of the Ling & IPC: 2 years & IPC: 5 years & IPC: 9 years & IPC: 4 years & IPC: 20 years \\
& TPS: 2 years & TPS: 5 years & TPS: 9 years & TPS: 4 years & TPS: I8 years \\
& TI: 0 months & TI: 7 months & TI: 5 months & TI:20 months & TI:28 months \\
\hline IA & $\times$ & $\times$ & $\times$ & $\times$ & $\times$ \\
I/ & - & $\times$ & - & $\times$ & $\times$ \\
N/ & $\times$ & $\times$ & - & $\times$ & $\times$ \\
IS/ & - & $\times$ & - & $\times$ & $\times$ \\
M/ & - & $\times$ & - & $\times$ & $\times$ \\
If/ & - & & - & & $\times$ \\
\hline
\end{tabular}

exchange of the component. The electrodes were introduced in the complete form in 7 of 9 patients, as soon as 2 had partial unilateral introduction. The telemetry was carried out intra-operatively one to assess the neural answer and the impedance of the introduced electrodes, and we had satisfactory results in both tests. The audiologicals evaluations after implantation are found in charts 4,5,6 and 7 , exception of the last 4 patients who did the surgery of implant were still not presenting sufficient time (1 month) for realization of this audiological evaluation, therefore, only the first 5 are shown in the charts. In the preoperative period, all patients underwent imaging examinations including CT and NMR, and in 1 was found enlargement of the vestibular aqueduct being an East, the patient in whom intraoperative hemorrhage occurred; however, they were not considered radiologically to counter-indicate the surgery. 


\section{DISCUSSION}

In the completed inquiry, we analyzed 9 records of patients who had undergone CI surgery in the period from May 2009 to February 2012 encompassing the age group from 2 to 46 years of age, 4 males and 5 females, which contrasted with other international and national reports of male domininace in the number of implants masculine $(5,6,7)$. This may be due to the low number of the sample overall. The diagnosis of the causes was diversified, 22.2\% maternal German measles, 22.2\% cytomegalovirus, $22.2 \%$ for ototoxicity, $22.2 \%$ meningitis, and $11.1 \%$ sudden deafness. This result also goes against the findings of other studies, which show etiology unknown as the main cause of sensorioneural deafness (8). The age at the time of surgery varied from 2 to 46 years, being that 6 of 9 patients had age varying from 2 to 9 years, a fact observed in other studies, where the surgery is carried out with greater frequency in children with deafness prelingual (8). Seven of 9 patients were classified as lingual-daily pay. The CIs used were Nucleus Freedom in 8 of 9 patients, and only 1 patient received the Sonata CI. In 2 of 9 patients, a straight electrodes bundle was used, since these patients had meningitis as an etiology of the deafness and so the possibility of a cochlea ossified providing bigger difficulty in the introduction of the bundle of electrodes. A third patient also did that I use the straight electrodes bundle when it needed to carry out the exchange of the appliance for fault of the internal device, this decision was taken thinking about the possibility of fibrosis, also making difficult the passage of the electrodes. In 7 of 9 patients, the implant was carried out bilaterally, which is a worldwide tendency, since it promotes a quicker hearing rehabilitation. The surgical complications can be classified as major when they require a new surgical approach or admission, and in juveniles even when the problem is resolved at the ambulatory level (19). A work carried out in Latin America encompassing 40 CI centers with a sample of 3,768 patients, presented a rate of $5.1 \%$ complications surgical-powders, being the spontaneous fault of the system to their principal (larger complication). Other studies of the same nature, had rates of major complications varying from 3 to $13.7 \%$ (10-13). In the present study, one patient $(12.5 \%)$ presented with complications due to the faulty internal component of the implant unilaterally, a major complication requiring a new surgical approach and another patient (12.5\%) presented with dizziness surgical-powders (minor complication). The patient candidates for the IC undergo an evaluation surgical-daily pay. In this evaluation, the imaging examinations including CT and NMR are carried out with the realization that they are of basic importance while making possible the identification of findings that would counter-indicate the surgery, assiting in the choice of the ear being introduced, assessing appropriately the anatomy of the area to be explored during the surgery and, inside their limitations, allowing a previsualization of areas of potential complications (3). The conjugated use of the CT and NMR of the result in better agreement of the obtained information and help the surgeon intraoperatively. We performed CT and NMR in all the 9 patients and observed enlargement of the vestibular aqueduct in 1 patient and incudomalleolar malformation in another. These imaging findings were not thought to be of relevance for contra-indication of surgery (3). However, they are important in order that the surgeon has notion of the potential intra-operating problems that can take place. Our patient who had enlargement of the vestibular aqueduct had in an intra-operative gusher, which took the same thing developing dizziness in the post-operative one. The intra-operative telemetry serves to assess the neural answer, obtaining satisfactory results regarding this test. The telemetry of impedances must always be carried out before the neural answer telemetry in order to confirm the appropriate functioning of the receiver and of the stimulation and to check the existence of open circuit or short circuit in the electrodes in cochlears from the measure of the electric resistance of mesmos (14). The objective to the telemetry happening in the intra-operating one is that, depending on the alteration, the surgeon can try to solve the problem before the closure of the cavity, re-positioning the electrodes, or deciding to substitute them if the number of electrodes with impedacias altered is big. The electrodes of the implanted cochlears were introduced in the complete form in 7 of 9 patients, as soon as 2 had partial introduction unilaterally; however, the introduced electrodes had good results to the intra-operating telemetry, equally to that what were introduced in the total form.

$\mathrm{CI}$ as treatment for hearing deficiency prelingual pay presents countless nuances. It is not simply to introduce surgically the appliance in the patient, and East was driven only by his device electronic (15). The implant cochlear is a process that wraps several stages: evaluation surgicaldaily pay, surgical act, and hearing rehabilitation. This rehabilitation is carried out by the professional of fonoaudiologia, what passes the informations to a medical otorhinolaryngologist of as the hearing development of the patients walks. Some factors influence the good development audiologico, I eat for example, the age in the moment of the surgery, the time of sensory deprivation, the time of use of the implant (16). We value also the hearing skills, the sounds of the ling, the hearing discrimination, and the categories of language at 5 of 9 patients. Four remaining patients carried out the surgery very recently and had not sufficient time to do this evaluation (Charts 4,5,6,7). 
The age in the surgery has been relevant in the results of the cochlear implant. Some studies showed what children introduced before 3 years of age reached quicker results regarding that what were operated in age more tardia $(17,18)$. Up to 6 years of age there is completed the development of the oral language, being that from this age, in averse situations, like the hearing deficiency, progresses do not take place so easily. In our study, where approximately $66.7 \%$ of the patients were below 9 years of age, good results were found regarding the analyzed categories: hearing skills, sounds of the ling, hearing discrimination, and categories of language.

It is natural that with bigger time of use of the implant and with the maturing inherent in the age, the children present satisfactory performance in tests (19). Some authors think that there is necessary a time of use of the cochlear implant of approximately 2 years for the proof of his benefits in young children. In our study, we already observed good results as for the studied variables, even before completing hmm year of implant, showing this to be a quite efficient treatment.

The time of hearing sensory deprivation influences the performance of when daily pay - linguais $(20,21)$ was introduced. We analyze this factor influence and observe good results, showing that the less the deprivation time, better the performance of the patient in the evaluated tests. The patient who was introduced to 20 years of age and who was presenting time of sensory deprivation of 18 years, also had turned out to be satisfactory, what it contradicts what was said previously; however, this patient from always did therapy fonoaudiologica, it had a good lip reading and it was still doing use of appliance of individual resonant enlargement (AASI). Another patient with 17 years did the surgery in spite of presenting sensory deprivation for the past 13 years. The surgery was carried out, in spite of the patient was lingual-powders, since the same thing was presenting a discreet degeneration of the language. Further, we had in our work patient when it was introduced to 46 years of age that had a time of sensory deprivation of 1 year due to sudden deafness (lingual-powders). Meantime, we still have not an evaluation fonoaudiologica of these 2 last patients since the surgery was carried out recently.

The children with deafness for cytomegalovírus present a more difficult evolution when compared with deaf children by others causes (22). In spite of the slowness in the progress of the hearing rehabilitation powders-implants, it does not make contra-indication to do the implant in these children. In our work, 2 children took the infection as a cause of the deafness for the cytomegalovírus and really they presented bigger difficulty in the evolution of the therapies when likened to others.

\section{CONClusion}

The cochlear implant is the form of already consolidated hearing rehabilitation and it comes being spread in different specialized centers in otoaudiologia. In this form, there is obvious the necessity of structured and professional services enabled in this type of proceeding.

\section{REFERENCES}

1. Luxford W, Brackmann D. The history of cochlear implantes. In: Gray R, ed. Cochlear implantes. San Diego: College Hill Press. 1985:10:1100-6.

2. Bevilacqua MC, Moret ALM, Costa Filho AO, Nascimento LT, Banhara MR. Implantes cocleares em crianças portadoras de deficiência auditiva decorrente de meningite. Braz J Otorhinolaryngol. 1994;60(4):1-16.

3. Lima Júnior LRP, Rocha MD, Walsb PV, Antunes CA, Calhau CMDF. Avaliação por imagem nos candidatos ao implante coclear: correlação radiológico-cirúrgica. Braz J Otorhinolaryngol. 2008;74(3):395-400.

4. Lima Júnior LRP, Rodrigues Júnior FA, Calhau CMDF, Calhau ACDF, Palhano CTP. Complicações pós-cirúrgicas em pacientes impantados no Programa de Implante Coclear do Rio Grande do Norte. Braz J Otorhinolaryngol. 2010;76(4):517-21.

5. Nóbrega, M. Deficiência auditiva na infância: a experiência do ambulatório de deficiência auditiva da UNIFESP/EPM. Anais do $17^{0}$ Encontro Internacional de Audiologia. Bauru; 2002.

6. Reis DC. Saúde auditiva em João Pessoa. [mestrado]. São Paulo (SP): Pontifícia Universidade Católica de São Paulo; 2006.

7. Egeli E, Ciçekci G, Silan F, Oztürk O, Harputluoglu U, Onur A et al. Etiology of deafness at the Yeditepe school for the deaf in Istanbul. Int J Pediatr Otorhinolaryngol. 2003;67(5):467-71.

8. Calháu CMDF, Lima Júnior LRP, Reis AMCS, Capistrano AKB, Lima DVSP, Calháu ACDF et al. Perfil etiológico dos pacientes implantados do Programa de Implante Coclear. Braz J Otorhinolaryngol. 2011; 77(1):13-8.

9. Cohen NL, Hoffman RA. Complications of cochlear implant 
surgery in adults and children. Ann Otol Rhinol Laryngol. 1991; 100:708-11.

10. Dutt SN, Ray J, Hadjihannas E, Cooper H, Donalds I, Proops D. Medical and surgical complications of the second 100 adult cochlear implant patients in Birmingham. J Laryngol Otol. 1996.

11.HoffmanRA, CohenNL-Complications of cochlearimplant surgery. Ann Otol Rhinol Laryngol. 1995;166:420-2.

12. Collins MM, Hawthorne MH, el Hmd K. Cochlear implantation in a district general hospital: problems and complications in the first five years. J Laryngol Otol. 1997;111:325-32.

13. Aschendorff A, Marangos N, Laszig R. Complications and reimplantation. Adv Otorhinolaryngol. 1997;52:167-70.

14. Lai W. An NRT Cookbook: Guidelines for making NRT measurements. 1st ed. Zürich: Cochlear AG; 1999.

15. O'neill, C, O'donoghue GM, Archbold SM, Nikolopoulos $\mathrm{TP}$, Sach T. Variations in gains in auditory performance from pediatric cochlear implantation. Otol Neurotol. 2002; 23(1):44-48.

16. Richter B, Eibele S, Laszig R, Löhle E. Receptive and expressive language skills of 106 children with a minimum of 2 years'experience in hearing with a cochlear implant. Int J Pediatr Otorhinolaryngol. 2002; 64(2):111-25.
17. Kirk KI, Miyamoto RT, Lento C L, Ying E, O'neill T, Fears B. Effects of age at implantation in young children. Ann Otol Rhinol Laryngol. 2002;111(5):69-73.

18. Baumgartner WD, Pok SM, Egelierler B, Franz P, Gstoettner W, HamzaviJ. The role of age in pediatric cochlear implantation. Int J Pediatr Otorhinolaryngol. 2002;62(3):22328.

19. Miyamoto RT, Houston DM, Kirk KI, Perdew AE, Svirsky MA. Language development in deaf infants following cochlear implantation. Acta Otolaryngol. 2003;123(2):24144.

20. Nicholas JG, Geers AE. Will they catch up? The role of age at cochlear implantation in the spoken language development of children with severe to profound hearing loss. J Speech Lang Hear Res. 2007;50(4):1048-62.

21. Flipsen P Jr, Colvard LG. Intelligibility of conversational speech produced by children with cochlear implants. J Commun Disord. 2006;39(2):93-108.

22. Ramirez IJM, Nikolopoulos TP. Cochlear Implantation in children deafened by cytomegalovirus: Speech perception and speech intelligibility outcomes. Otology \& Neurotology. 2004;25(4):479-82. 